\title{
Understanding the Potential of Bio-Carbon Capture and Storage from Biomass Power Plant in Indonesia
}

\author{
Zefania Praventia Sutrisno ${ }^{1, *}$, Attaya Artemis Meiritza ${ }^{1}$, Anggit Raksajati ${ }^{1,2}$ \\ ${ }^{1}$ Department of Chemical Engineering, Faculty of Industrial Technology, Institut Teknologi Bandung, \\ Jalan Ganesha No.10, Bandung 40132, Indonesia \\ ${ }^{2}$ Center of Excellence (CoE) of CCS-CCUS, Institut Teknologi Bandung, Jalan Ganesha No.10, \\ Bandung 40132, Indonesia
}

Received 25 January 2021; Accepted 22 February 2021

Available online 26 February 2021

\begin{abstract}
Indonesia is currently experiencing a significant increase in population, industrialization and energy demand. As the energy demand increases, so does the production of climate-altering $\mathrm{CO}_{2}$ emission. Biomass power plants have emerged as a low carbon power generation alternative, utilizing agricultural and industrial waste. Biomass power plants have the potential of being a carbon-negative power generation technology in the near future by integrating carbon and capture storage (bio-CCS). The objective of this paper is to analyze and map potential $\mathrm{CO}_{2}$ emission in the processes of biomass power plants from gasification and firing or co-firing technology, then recommend suitable carbon capture technology based on the biomass power plant characteristics in Indonesia. The $\mathrm{CO}_{2}$ emission to be captured in the gasification process is $11-15 \%$ of the producer gas, while in co-firing it is $7-24 \%$ of the flue gas stream. Using biomass instead of coal in power plants reduces the electric efficiency and increases the plant's in-house emission, but when analyzed in a wider boundary system it is apparent that the net GWP and $\mathrm{CO}_{2}$ emission of biomass power plants are way smaller than coal power plant, moreover when equipped with carbon capture unit. Biomass power plant that uses firing technology can reduce $\mathrm{CO}_{2}$ emission by $148 \%$ compared to typical coal power plant. Installing carbon capture unit in biomass firing power plants can further reduce the specific $\mathrm{CO}_{2}$ emission by $262 \%$. If carbon capture technology is implemented to all existing biomass power plants in Indonesia, it could reduce the greenhouse gas emission up to 2.2 million tonnes $\mathrm{CO}_{2}$ equivalent annually. It is found that there are 3 significant designs for gasification technology: NREL design, Rhodes \& Keith design and IGBCC+DeCO2 design. The first two designs are not suitable to be retrofitted into existing biomass power plants in Indonesia since they are based on a specific BCL/FERCO gasifier. While IGBCC+DeCO ${ }_{2}$ design still needs further study regarding its feasibility. While for firing, the most promising technology to be applied in the near future is solvent-based absorption because it is already on commercial scale for coal-based power plants and can be implemented for other source, e.g. biomass power plant. Bio-CCS in existing biomass power plant with firing technology is likely to be implemented in the near future compared to the gasification, because it applies the post combustion capture as an "end-of-pipe" technology which is generally seen as a more viable option to be retrofitted to existing power plants, resulting in potentially less expensive transition.
\end{abstract}

Keywords: empty fruit bunch, bio-CCS, biomass, gasification, firing

\section{Introduction}

Indonesia is an emerging middle income country that currently is experiencing rapid economic expansion, industrialization and urbanizations. As a result, the demand for energy consumption per capita has increased steadily over the past decade. On average, total energy consumption has increased by $3 \%$ every year since 2010 . On top of that, the primary energy supply in Indonesia is still highly dependent on fossil fuels like oil, natural gas and coal, contributing up to $91 \%$ energy mix in 2018 (Suharyati et al., 2019).

*Corresponding author

E-mail address: zefaniapraventiasa@gmail.com 


\subsection{Current Energy Situation in Indonesia}

According to Indonesia Energy Outlook 2019, primary energy supply in business as usual (BaU) scenario in 2025 and 2050 is projected to reach 314 MTOE and 943 MTOE. Energy demand, especially the need for electricity, becomes more substantial in relation with the growth of technology and industry. Since the demand will keep increasing, fossil energy sources are still the feasible main option to fulfill the demand until 2050. However, new and renewable energy (NRE) is also considered to be a promising energy source. The Ministry of Energy and Mineral Resources (ESDM) has predicted that NRE's share will increase to $29 \%$ of the total energy mix in BaU scenario. In the sustainable development (PB) scenario and low carbon (RK) scenario, NRE is even expected to be the main energy source by 2050 .

Among the promising NREs in Indonesia are hydro power, geothermal, solar cell and non-household biomass. Given its geographic location and large size, the potential of biomass resources in Indonesia is relatively abundant, especially in Sumatera, Irian Jaya, Kalimantan and Sulawesi. According to calculations made by ZREU in 2010, potential energy produced from biomass is around 470 million GJ/year. This number is higher than in 2007, which was 441 million GJ/year. Another calculation made by Prastowo in 2012 also shows that for about a decade, the potential for biomass energy production has increased rapidly.

Indonesia is known as the largest palm oil producer in the world after overtaking Malaysia in 2006, with 5.73 million hectares plantation area in 2010 (Permatasari et al., 2011). Solid biomass waste from forestry, agriculture and plantations are the most potent first waste. Figure 1 illustrates the distribution of biomass potential in Indonesia.

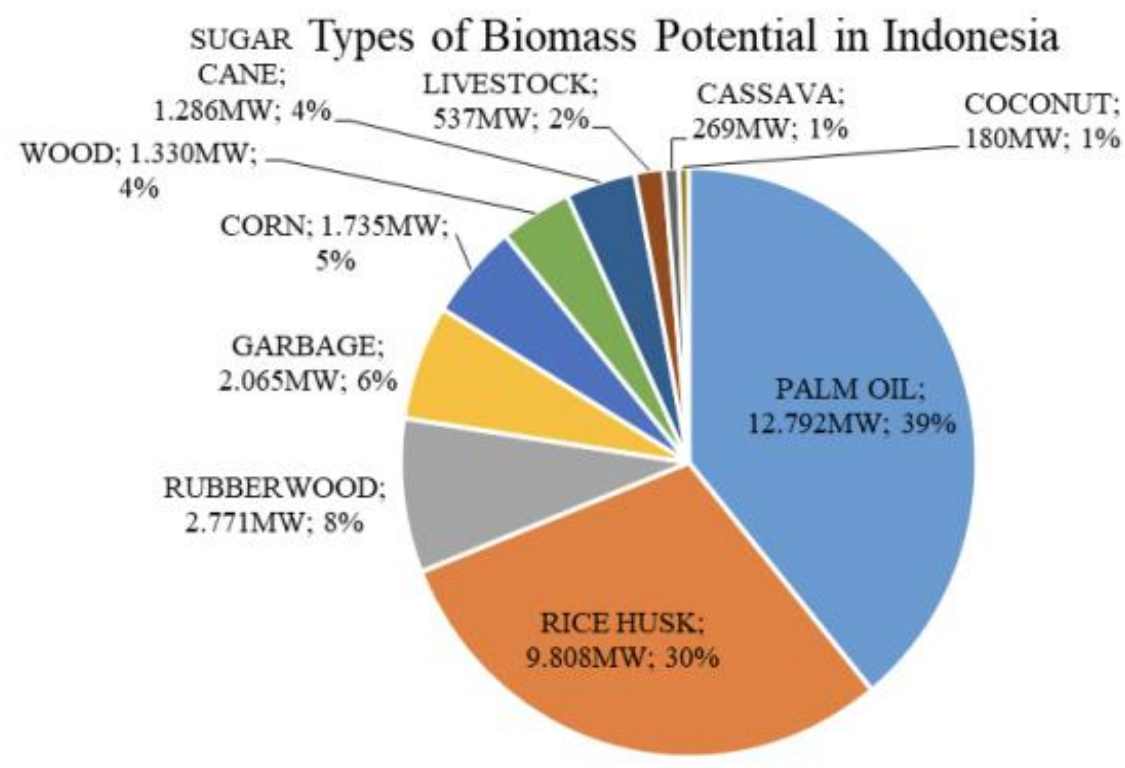

Figure 1. Types of biomass potential in Indonesia based on survey done in 2019 (Primadita et al., 2020).

Even though the energy potential of biomass is enormous and keeps increasing, its utilization is still very limited. Based on the data acquired from the national energy council, from the total potential of 32,654 MW only about 1,716 MW was utilized for electricity generation, or only a little over 5\% (Fitriana et al., 2017). This situation is unfortunate since biomass may provide a huge contribution in Indonesia's energy mix and eventually play a crucial role in helping the utility to provide energy security for the country. Besides its abundance in nature, biomass is also considered to be environmentally friendly, has constant supply and relatively easy to be integrated into the existing infrastructure. 


\subsection{Development of PLTBm and Bio-CCS}

There are several ways to utilize biomass and convert it into energy or electricity, one of which is through a biomass power plant (Pembangkit Listrik Tenaga Biomassa in Indonesia or abbreviated as PLTBm). In PLTBm, the power plant generates electricity by using biomass as a feedstock. ESDM (2020) defines PLTBm as the use of firing, co-firing, gasification technologies while biogas or modern landfill are classified as a different category. ESDM also stated that $4 \%$ of the national electricity production comes from PLTBm in 2018. This percentage is hoped to increase by substituting $30 \%$ of the current coal power plant capacity into PLTBm for the low carbon scenario.

The firing method, both biomass-only and biomass co-firing, are considered to be fully commercialized. Over the past decade, direct co-firing has achieved significant progress and has been demonstrated with many technology options and with a wide range of biomass feedstocks (CTCN, 2014). Whereas for gasification method is still limited to small-scale plant using largely waste and has not yet advanced to commercial-scale. Gasifier would typically provide fuel for commercial power generation or as a source of heat and power to meet major industrial needs (Rycroft, 2019). In Indonesia, the development of power plants that use biomass fuels on a large scale and was first recorded was in 2010, and is continuously developing until today.

Recently, the concept of combining bioenergy in PLTBm with carbon capture technology has been put forward as a way of producing carbon-negative power. This combination of technology is better known as Bio-CCS or sometimes BECCS, in which the $\mathrm{CO}_{2}$ generated from the power generation process will be captured and stored. The negative emissions are possible if the $\mathrm{CO}_{2}$ stored is greater than the $\mathrm{CO}_{2}$ emitted during biomass production, transport and utilization (Consoli, 2019). Bio-CCS is still a relatively novel concept and has only been experimented in laboratory and pilot scale. The topic of BioCCS development and its technology readiness level (TRL) will be discussed in the later part of the study.

\subsection{Existing PLTBm in Indonesia}

As an effort to achieve the $29 \%$ NRE in national energy mix, Indonesia's government pushes the development of PLTBm. Efforts have been made to process agricultural and industrial organic waste to promote circularity in various industries by utilizing PLTBm. Conversion and combustion of biomass into electricity generates less air emissions than fossil fuels. It also reduces the quantity of waste going to the landfill (Gokcol et al., 2009). Thus, PT PLN (State Electricity Company) maps the potential of biomass and supports its development to align with Indonesia's commitment on climate mitigation. Data of biomass power plants in Indonesia can be seen in Table 1. Both in-house and commercial PLTBm with PPA (power purchase agreement) are included in the table.

Table 1. Biomass power plants established in Indonesia.

\begin{tabular}{|c|c|c|c|c|c|}
\hline Name & Location & Resources & Technology & Capacity & Reference \\
\hline $\begin{array}{c}\text { PLTBm } \\
\text { North Sumatra } \\
\text { (Growth Steel } \\
\text { Group) }\end{array}$ & $\begin{array}{c}\text { Medan Industrial } \\
\text { Area (I,II, III), } \\
\text { Medan Deli, } \\
\text { North Sumatra }\end{array}$ & $\begin{array}{c}\text { Palm waste, } \\
\text { agricultural } \\
\text { waste }\end{array}$ & Co-Firing & $\begin{array}{c}30 \mathrm{x} 2 \\
\text { MW, 15 } \\
\text { MW }\end{array}$ & $\begin{array}{c}\text { Growth Asia, } \\
2012\end{array}$ \\
\hline $\begin{array}{c}\text { PLTBm North } \\
\text { Sumatera (PT } \\
\text { Harkat }\end{array}$ & $\begin{array}{c}\text { Simalungun, } \\
\text { North Sumatera }\end{array}$ & $\begin{array}{c}\text { Palm waste, } \\
\text { agricultural } \\
\text { waste }\end{array}$ & Firing & $30 \mathrm{MW}$ & Winarto, \\
$\begin{array}{c}\text { Sejahtera) } \\
\begin{array}{c}\text { PLTBm Batang } \\
\text { Kulim (PT. } \\
\text { Musimas) }\end{array}\end{array}$ & $\begin{array}{c}\text { Batang Kulim, } \\
\text { Riau }\end{array}$ & $\begin{array}{c}\text { Palm waste, } \\
\text { agricultural } \\
\text { waste }\end{array}$ & Gasification & $2 \mathrm{MW}$ & $\begin{array}{c}\text { Sudaryanti et } \\
\text { al., 2017; } \\
\text { Tobari, 2016 }\end{array}$ \\
\hline PLTBm Bangka & Bangka Belitung & Palm waste & Firing & $18 \mathrm{MW}$ & Agustiyanti, \\
\hline
\end{tabular}




\begin{tabular}{|c|c|c|c|c|c|}
\hline $\begin{array}{c}\text { Belitung } \\
\text { (Kencana Agri } \\
\text { Ltd) }\end{array}$ & & & & & 2017 \\
\hline $\begin{array}{l}\text { PLTBm West } \\
\text { Kalimantan (PT } \\
\text { Rezeki Perkasa } \\
\text { Sejahtera) }\end{array}$ & $\begin{array}{l}\text { Siantan, } \\
\text { Mempawah } \\
\text { Regency, West } \\
\text { Kalimantan }\end{array}$ & $\begin{array}{l}\text { Palm waste, } \\
\text { agricultural } \\
\text { waste }\end{array}$ & Gasification & $15 \mathrm{MW}$ & $\begin{array}{l}\text { Pahlevi, } \\
2018\end{array}$ \\
\hline $\begin{array}{l}\text { PLTBS Aceh } \\
\text { Tamiang (PT } \\
\text { Primanusa } \\
\text { Energi Lestari) }\end{array}$ & $\begin{array}{l}\text { Karang Baru, } \\
\text { Aceh Tamiang, } \\
\text { Banda Aceh }\end{array}$ & $\begin{array}{l}\text { Palm waste, } \\
\text { agricultural } \\
\text { waste }\end{array}$ & Firing & $9.8 \mathrm{MW}$ & $\begin{array}{c}\text { Primanusa } \\
\text { Energi } \\
\text { Lestari, 2013 }\end{array}$ \\
\hline $\begin{array}{l}\text { PLTBm Jambi } \\
\text { (PT Rimba } \\
\text { Palma Sejahtera } \\
\text { Lestari) }\end{array}$ & Jambi, Sumatra & Palm waste & Firing & $30 \mathrm{MW}$ & $\begin{array}{l}\text { Costa, 2014; } \\
\text { Primadita et } \\
\text { al., } 2020\end{array}$ \\
\hline $\begin{array}{c}\text { PLTBm PT } \\
\text { Harkat Sejahtera }\end{array}$ & $\begin{array}{l}\text { Simalunggun, } \\
\text { North Sumatera }\end{array}$ & $\begin{array}{l}\text { Agricultural } \\
\text { waste, wood }\end{array}$ & Firing & $2 \times 15 \mathrm{MW}$ & $\begin{array}{c}\text { Listrik } \\
\text { Indonesia, } \\
\text { 2012; PT } \\
\text { Growth Asia, } \\
2012\end{array}$ \\
\hline $\begin{array}{c}\text { PLTBm } \\
\text { Ketapang (PT } \\
\text { PJB) }\end{array}$ & $\begin{array}{l}\text { Ketapang, West } \\
\text { Kalimantan }\end{array}$ & Palm shells & Co-firing & 2x10 MW & $\begin{array}{c}\text { Listrik } \\
\text { Indonesia, } \\
\text { 2012; PT } \\
\text { Growth Asia, } \\
2012\end{array}$ \\
\hline $\begin{array}{l}\text { PLTBm } \\
\text { Sanggau (PT } \\
\text { PJB) }\end{array}$ & $\begin{array}{l}\text { Sanggau, West } \\
\text { Kalimantan }\end{array}$ & Palm shells & Co-firing & 2x7 MW & ESDM, 2020 \\
\hline $\begin{array}{c}\text { PLTBm } \\
\text { Pulubala (PLN) }\end{array}$ & $\begin{array}{l}\text { Gorontalo, } \\
\text { Sulawesi }\end{array}$ & Corn cobs & Gasification & $500 \mathrm{~kW}$ & $\begin{array}{l}\text { Primadita et } \\
\text { al., 2020; } \\
\text { Wicaksono, } \\
2014\end{array}$ \\
\hline $\begin{array}{l}\text { PLTBm Riau } \\
\text { (PT. Indah Kiat } \\
\text { Pulp and Paper) }\end{array}$ & $\begin{array}{c}\text { Perawang, Minas, } \\
\text { Riau }\end{array}$ & Palm waste & Co-Firing & $3 \mathrm{MW}$ & $\begin{array}{l}\text { PT SMI, } \\
2017\end{array}$ \\
\hline $\begin{array}{l}\text { PLTBm Banten } \\
\text { (PT Indocoke) }\end{array}$ & Cilegon, Banten & Palm shells & Co-Firing & $30 \mathrm{MW}$ & $\begin{array}{l}\text { BUMN, } \\
2021\end{array}$ \\
\hline $\begin{array}{l}\text { PLTBm Riau } \\
\text { (PT Meskom } \\
\text { Agro Sarimas) }\end{array}$ & $\begin{array}{c}\text { Bantang, } \\
\text { Bengkalis, Riau }\end{array}$ & Palm waste & Gasification & $10 \mathrm{MW}$ & $\begin{array}{l}\text { Primadita et } \\
\text { al., } 2020\end{array}$ \\
\hline $\begin{array}{c}\text { PLTBm PT } \\
\text { Biogreen Power } \\
\text { Kobar }\end{array}$ & $\begin{array}{l}\text { Desa Nanga Mua, } \\
\text { Kotawaringin, } \\
\text { South Kalimantan }\end{array}$ & Palm shells & Firing & $10 \mathrm{MW}$ & $\begin{array}{l}\text { Himawan, } \\
2017\end{array}$ \\
\hline $\begin{array}{l}\text { PLTBm Bambu } \\
\text { Siberut (PT Inti } \\
\text { Karya Persada } \\
\text { Tehnik) }\end{array}$ & $\begin{array}{l}\text { Siberut Island, } \\
\text { Mentawai, West } \\
\text { Sumatera }\end{array}$ & $\begin{array}{l}\text { Raw bamboo, } \\
\text { Forest residue }\end{array}$ & Gasification & $700 \mathrm{~kW}$ & IKPT, 2019 \\
\hline $\begin{array}{l}\text { PLTBm Siberut } \\
\text { (PT Charta } \\
\text { Putra Indonesia } \\
\text { and IKPT) }\end{array}$ & $\begin{array}{c}\text { Siberut, } \\
\text { Mentawai, West } \\
\text { Sumatra }\end{array}$ & Wood waste & Gasification & $700 \mathrm{~kW}$ & IKPT, 2019 \\
\hline
\end{tabular}




\begin{tabular}{|c|c|c|c|c|c|}
\hline $\begin{array}{c}\text { PLTBm } \\
\text { Tanjung Balai } \\
\text { Karimun (PT } \\
\text { PT Prima } \\
\text { Gasifikasi } \\
\text { Indonesia) }\end{array}$ & $\begin{array}{l}\text { Tanjung Balai } \\
\text { Karimun, Riau }\end{array}$ & Wood & Gasification & $1.2 \mathrm{MW}$ & $\begin{array}{l}\text { Kusuma, } \\
2019\end{array}$ \\
\hline $\begin{array}{c}\text { PLTBm } \\
\text { Mersam (PT } \\
\text { Karya Energi } \\
\text { Jambi) }\end{array}$ & Mersam, Jambi & $\begin{array}{l}\text { Empty fruit } \\
\text { bunch }\end{array}$ & Gasification & $3 \mathrm{MW}$ & $\begin{array}{l}\text { Jonan, 2018; } \\
\text { REEP \& } \\
\text { LCORE- } \\
\text { INDO, } 2017\end{array}$ \\
\hline $\begin{array}{c}\text { PLTBm } \\
\text { Sukamara (PT } \\
\text { Fajar Mitra } \\
\text { Energi) }\end{array}$ & $\begin{array}{l}\text { Balai Riam, } \\
\text { Sukamara, } \\
\text { Central } \\
\text { Kalimantan }\end{array}$ & $\begin{array}{l}\text { Palm kernel } \\
\text { shell }\end{array}$ & Firing & $10 \mathrm{MW}$ & $\begin{array}{l}\text { Himawan, } \\
2017\end{array}$ \\
\hline $\begin{array}{l}\text { PLTBm Sintang } \\
\text { (PT Intika } \\
\text { Accord Power) }\end{array}$ & $\begin{array}{l}\text { Tebelian River, } \\
\text { Sintang, West } \\
\text { Kalimantan. }\end{array}$ & $\begin{array}{l}\text { Palm kernel } \\
\text { shell }\end{array}$ & Firing & $10 \mathrm{MW}$ & $\begin{array}{l}\text { Boothman, } \\
2017\end{array}$ \\
\hline $\begin{array}{c}\text { PLTBm Sintang } \\
\text { (PT Carpediem } \\
\text { Elektrikan } \\
\text { Nusantara) }\end{array}$ & $\begin{array}{l}\text { Empaci, Sintang, } \\
\text { West Kalimantan }\end{array}$ & $\begin{array}{l}\text { Palm waste, } \\
\text { wood, bamboo }\end{array}$ & Firing & $10 \mathrm{MW}$ & Rahino, 2017 \\
\hline $\begin{array}{c}\text { PLTBm Kubu } \\
\text { Raya (PT Pundi } \\
\text { Global } \\
\text { Investama) }\end{array}$ & $\begin{array}{c}\text { Korek, } \\
\text { Ambawang, Kubu } \\
\text { Raya, West } \\
\text { Kalimantan }\end{array}$ & $\begin{array}{l}\text { Palm kernel } \\
\text { shell }\end{array}$ & Firing & $4 \mathrm{MW}$ & $\begin{array}{l}\text { Boothman, } \\
2017\end{array}$ \\
\hline $\begin{array}{c}\text { PLTBm Aceh } \\
\text { Tamiang (PT } \\
\text { Biomas Energy } \\
\text { Abadi) }\end{array}$ & Aceh Tamiang & Palm waste & Firing & $10 \mathrm{MW}$ & $\begin{array}{l}\text { Firsawan, } \\
2018\end{array}$ \\
\hline
\end{tabular}

\subsection{Bio-CCS Role in Indonesia's Climate Change Mitigation}

Indonesia is highly susceptible to the impacts of climate change mainly due to its economic and geographical conditions. As one of the largest greenhouse gas emitters, Indonesia has the responsibility to show their commitment in cutting its climate-altering pollution. As in 2015, Indonesia's annual greenhouse emissions were $2.4 \mathrm{GtCO} 2 \mathrm{e}$, representing $4.8 \%$ of the world's total emission that year. Moreover, its per-capita emissions were 9.2 tonnes $\mathrm{CO}_{2}$, higher than the global average, EU and even China. Figure 2 shows the source Indonesia's GHGs emission according to each sector.

Besides the fluctuating emission from the peat fire, the energy sector consistently contributes as the majority emission source most years. According to Indonesia's Nationally Determined Contribution 2016, Indonesia had pledged to reduce its $\mathrm{CO}_{2}$ emission by $29 \%$ in 2030 to the UNFCCC in the lead up to the Paris climate conference. Therefore, it is extremely crucial for the energy sector to discover a way to suppress the $\mathrm{CO}_{2}$ emission produced by implementing low carbon processes.

Retrofitting Bio-CCS to existing infrastructure can significantly reduce the $\mathrm{CO}_{2}$ emission generated by the energy sector, it is the most viable and cost-effective method to achieve net negative emission. Furthermore, the IPCC has stated that carbon-negative value chains are required in order to stay within the maximum $2{ }^{\circ} \mathrm{C}$ target set on the Paris Agreement. 


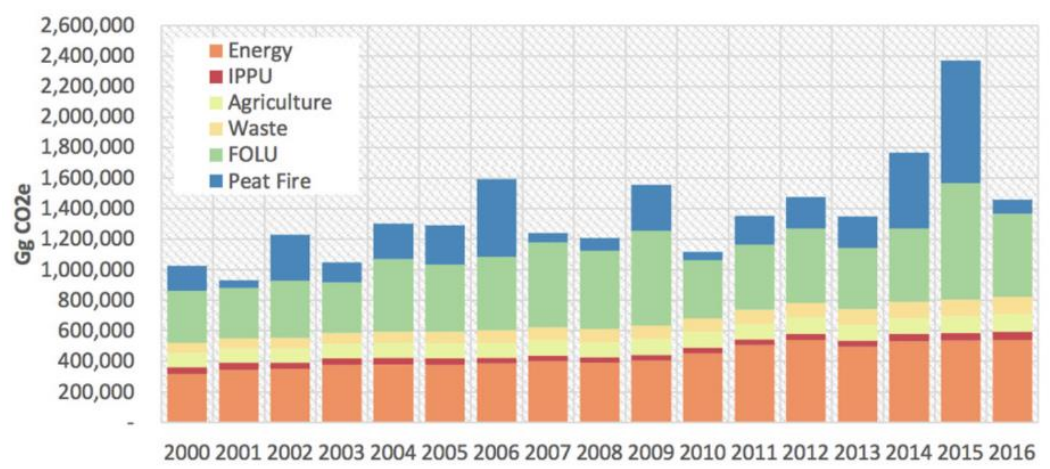

Figure 2. Indonesia's total emission divided by each sector 2000 - 2016 (Kementrian Lingkungan Hidup dan Kehutanan, 2017).

Achieving a carbon negative development does not only mean being able to meet the target set by NDC and the IPCC. Low-carbon development will also contribute to GDP growth, increase in the quantity and quality of jobs, which are greener and better paid. It also can prevent deaths by 40,000 people annually due to increase in air and water pollution, not to mention the deaths that can be prevented from climate change-related natural disasters. Importantly, a greener and more sustainable country will also offer better value to investors compared to countries that grow through the extraction and fossil fuel use (Garrido, 2019).

\subsection{Objective of The Study}

Indonesia is currently experiencing a significant increase in population, industrialization and energy demand. As the energy demand increases, so does the production of climate-altering $\mathrm{CO}_{2}$ emission. Due to its geographical conditions, Indonesia is highly susceptible to the impacts of climate change. Therefore, it is critical for us to find a more environmentally friendly alternative in the industry to generate power. Considering Indonesia's abundant biomass reserves, PLTBm has emerged as a promising candidates in the recent years. PLTBm in Indonesia uses firing or co-firing and gasification technology. Some established PLTBm are equipped with PPA and some are utilized for in-house waste to energy application. PLTBm are common in palm oil plantations and mills, using palm waste as a resource. This paper focuses on existing PLTBm in Indonesia.

The objective of this paper is to firstly analyze and map $\mathrm{CO}_{2}$ emission in the processes of PLTBm, comparing co-firing, firing and gasification technology pathways. This paper focuses on the said technologies to generate electricity from biomass that have been applied commercially in Indonesia. A comparison is also applied for the performance of PLTBm, PLTBm equipped with carbon capture unit and typical coal power plant in regard of their emission. These comparisons are done to give an understanding on the potential of PLTBm as a low carbon power generation route, including the performance difference of various biomass power generation technology. The establishment of PLTBm in Indonesia are reviewed and listed, including the used technology. Several designs for carbon capture in PLTBm are then explored to conclude which design is recommended to be retrofitted in PLTBm of Indonesia based on the technological feasibility.

\section{Method}

The scope of this study points to the identification of emission in existing PLTBm of Indonesia and technology recommendation of existing bio-CCS designs. The study is done through 3 phases as seen in Figure 3: mapping research field and object, data collection and treatment, prescriptive analysis. The mapping research field and object phase is conducted through literature review on primary and secondary sources, such as academic journals, statistics and other corresponding publications. 


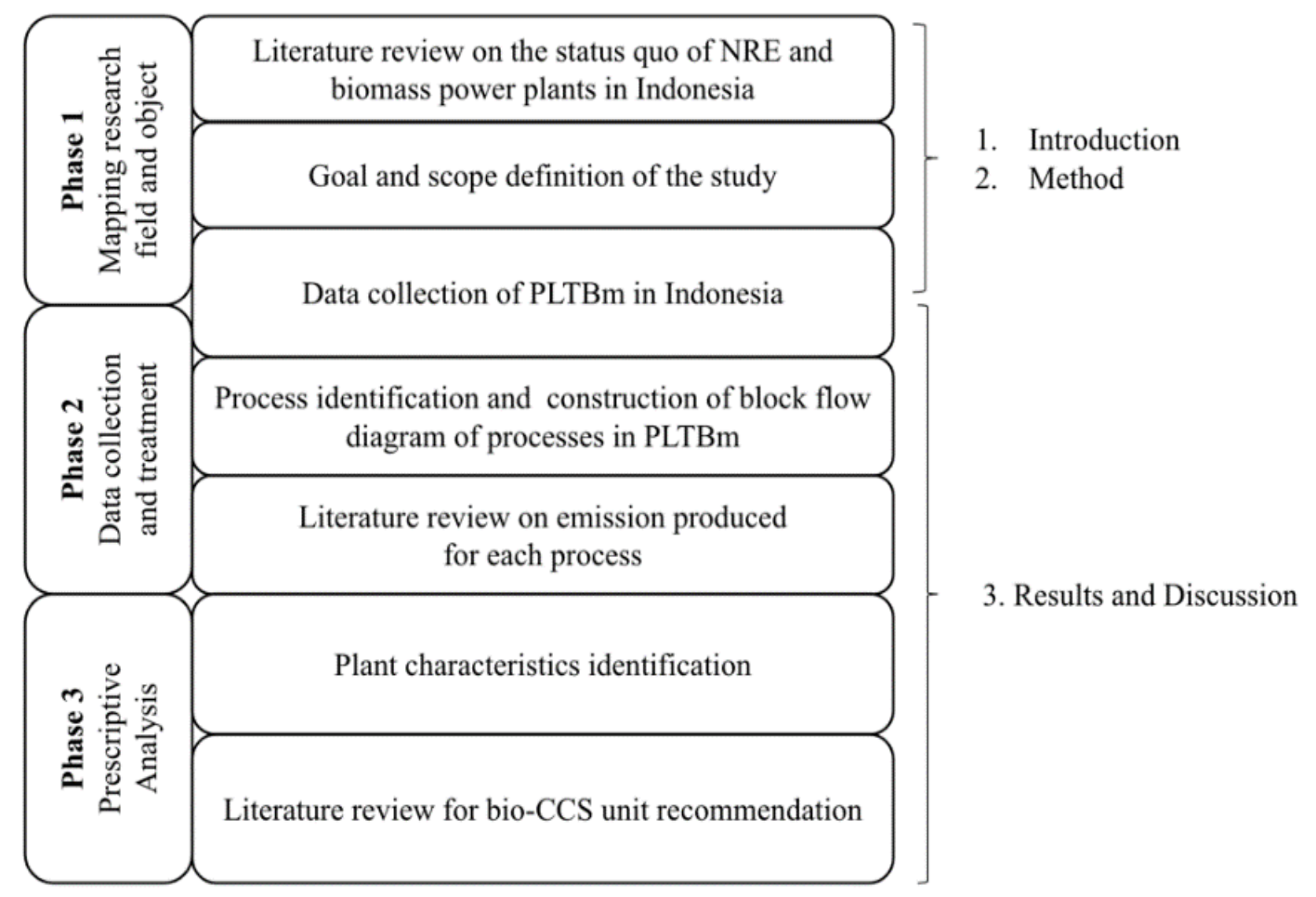

Figure 3. Schematic diagram of the method in this study.

Data collection and treatment phase is done quantitatively and qualitatively. Quantitative analysis is done by literature review of life cycle assessment (LCA) and carbon emission intensity. Two comparisons based on literatures are made. Firstly, LCA and carbon emission intensity literatures on gasification, firing, co-firing of biomass with similar system boundaries are reviewed. The selected data are taking the emissions in the power plant sub-system only (gate-to-gate), excluding the feedstock production or other full cradle-to-grave activities.

The data for gasification process is taken from Mann and Spath (1997) who assessed a cradle-to-gate LCA on IBGCC (Integrated Biomass Gasification Combined Cycle) of a BCL/FERCO Gasifier with wood feedstock. Mann and Spath detailed all sub-systems used in the LCA process, including the emission production at each sub-system. For the plant sub-system, the emission calculation was taken by simulating the model on ASPEN Plus ${ }^{\mathrm{TM}}$ using experimental data of a BCL process development unit in existing literatures. The emission of the feedstock preparation (drying) and power generation process are taken from various literatures and included in the calculation using TEAM (Tools for Environmental Analysis and Management) software. Thus, the $\mathrm{CO}_{2}$ emission for the plant sub-system can be taken from this literature.

Wiley et al. (2013) calculated the $\mathrm{CO}_{2}$ emission of a $10 \%$ wood waste co-firing plant based on a black coal Australian power plant. The emission calculation was done by implementing Tillman's formula of efficiency loss as a function of biomass mix in the feedstock blend on the base coal power plant. Then, emission factor for both coal and biomass are applied to the carbon emission intensity calculation process. While for direct firing of wood, a reported emission data of the operation in Burlington Plant, Vermont is taken (EREN, 2001 as cited in Carpentieri et al., 2004). These numbers are compared to understand emission comparison in various PLTBm technologies.

Then, a comparison on a cradle-to-grave LCA is done for various power plant cases based on Mann and Spath (2004) LCA report: coal power plant, PLTBm (firing and gasification), PLTBm with CCS. The emission compared includes the biomass sourcing/ plantation, transportation, construction and power generation. It also includes the power needed for additional carbon capture technologies in the cases 
where CCS is applied. The power plant and carbon capture unit are based on a previous study by Hendriks (1994). The carbon capture unit used is optimized monoethanolamine (MEA) design. The storage is assumed to be an underground carbon sequestration. Emissions of all sub-systems are taken from various literatures. These numbers are comparable since Mann and Spath used similar assumptions for all cases.

Further review on existing technologies and designs of carbon capture is done. The review is limited for gasification and co-firing/firing technology only. Co-firing and firing can use the same carbon capture unit due to exact same process. Prescriptive analysis is then carried on to give recommendations on the suitable bio-CCS unit retrofitted in PLTBm of Indonesia.

\subsection{Comparison of PLTBm Technology}

As it can be seen in Table 1, there are two common technology used for PLTBm in Indonesia: firing or co-firing and gasification. In general, the comparison of both technologies can be seen in Table 2 below.

Table 2. Comparison between firing and gasification technology.

\begin{tabular}{|c|c|c|}
\hline Fuel & Gasification & Firing \\
\hline Oxygen supply & $\begin{array}{c}\text { Biomass is processed in gasifier } \\
\text { to produce syngas that will be } \\
\text { used for combustion }\end{array}$ & $\begin{array}{c}\text { Biomass is directly used in } \\
\text { combustion process }\end{array}$ \\
\hline $\begin{array}{c}\text { Typical Operating } \\
\text { Temperature }\end{array}$ & Below $750^{\circ} \mathrm{C}$ & $\begin{array}{c}\text { More than stoichiometric oxygen } \\
\text { (supplied with excess air) }\end{array}$ \\
\hline $\begin{array}{c}\text { Carbon Capture Unit } \\
\text { Type }\end{array}$ & $\begin{array}{c}\text { Pre-combustion }\left(\mathrm{CO}_{2} \text { captured }\right. \\
\text { from the producer gas) }\end{array}$ & $\begin{array}{c}\text { Post-combustion }\left(\mathrm{CO}_{2} \text { captured }\right. \\
\text { from the flue gas) }\end{array}$ \\
\hline
\end{tabular}

\subsection{Block Flow Diagram of PLTBm with Gasification Technology}

PLTBm with gasification technology in Indonesia converts agricultural and industrial waste (wood, rice husks, corn cobs, bagasse, sawdust, palm waste) using gasification technology and typically water tube boiler (Padang et al., 2020; Primadita et al., 2020). The process of PLTBm with gasification technology is as depicted in Figure 4. Feedstocks are grounded into finer form. It is then put into a gasifier, supplied with oxygen less than the stoichiometric combustion needs to produce combustible gas known as producer gas (Sansaniwal et al., 2017). The carbon capture unit should be placed after the gasification process so that the $\mathrm{CO}_{2}$ in the stream is more concentrated, making it more efficient. In gasification reactions, the amount of oxygen available inside the gasifier is controlled so that only a portion of the fuel burns completely (Ciferno et al., 2007). Therefore, the carbon capture unit installed is the precombustion. 


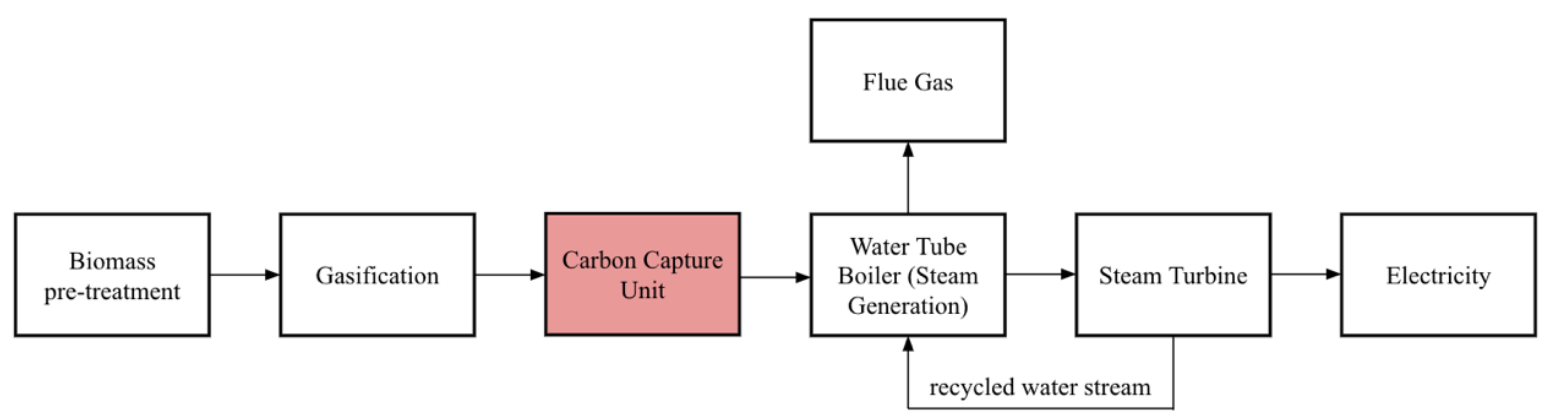

Figure 4. Block flow diagram of the process in PLTBm with gasification technology. Red box represents the carbon capture unit to be installed if Bio-CCS is implemented in PLTBm with gasification technology.

The carbonaceous feedstock undergo a series of reactions in the gasifier. As reported by E4Tech (2009), the reactions are as follow:

$$
\begin{gathered}
\mathrm{C}_{(\mathrm{s})}+\mathrm{O}_{2(\mathrm{~g})} \rightarrow \mathrm{CO}_{2(\mathrm{~g})} \\
\mathrm{C}_{(\mathrm{s})}+\mathrm{H}_{2} \mathrm{O}_{(\mathrm{g})} \rightarrow \mathrm{CO}(\mathrm{g})+\mathrm{H}_{2(\mathrm{~g})} \\
\mathrm{CO}_{(\mathrm{g})}+\mathrm{H}_{2} \mathrm{O}_{(\mathrm{g})} \leftrightarrow \mathrm{CO}_{2(\mathrm{~g})}+\mathrm{H}_{2(\mathrm{~g})}
\end{gathered}
$$

The first reaction provides heat for gasification by the release of volatile compound and $\mathrm{C}$ combustion. The second reaction begins the gasification process, releasing carbon monoxide. The carbon monoxide later reaches equilibrium via water-gas shift reaction (WGSR). Palm waste generates producer gas with composition (v/v\%) of 19-24\% CO, 10-15\% $\mathrm{H}_{2}, 11-15 \% \mathrm{CO}_{2}$ (Hoeglund, 1981 as cited in Sansaniwal et al., 2017). There are also trace amounts of hydrocarbons (Mohammed et al., 2012).

Other power generation routes such as gas turbines require an intensive purification process while steam power plants can readily use the producer gas directly (Asadullah, 2014). The producer gas is combusted with oxygen to generate heat for a water tube boiler. The boiler then generates steam as the prime mover. The steam turns the turbine, turning mechanical energy into power output (Khalil, 2008). Flue gas consists of the non-combustible $\mathrm{CO}_{2}$ gas and other compounds due to incomplete combustion is released, while the ash is used as fertilizer.

\subsection{Block Flow Diagram of PLTBm with Firing or Co-firing Technology}

In PLTBm that utilizes firing technology, the direct combustion of biomass in the presence of excess air results in the formation of hot gases that are typically used to produce steam using boilers. The process for firing technology can be seen in Figure 5. The same process applies for co-firing. Co-firing uses a mix of coal and biomass, while firing only uses biomass. For this case, because the biomass is used directly as a fuel, the carbon capture unit will be installed right after the combustion process, sequestrating $\mathrm{CO}_{2}$ from the flue gas. This carbon capture process is known as post-combustion CCS.

In Indonesia, the most common application for this method is co-firing, in which the biomass feedstocks are mixed with existing fossil-based fuel, mostly pulverised coal (IEA Bioenergy, 2009). According to Engström (1999), two distinct techniques are available to co-fire biofuels in utility boilers; (1) biomass and/or other opportunity fuels are blended with coal and the blend is transported through the crusher and further to the firing system; or (2) the biofuel is prepared separately from the coal and injected into the boiler without impacting the coal. The second approach is preferred for boiler firing with $>10 \%$ biomasses. 


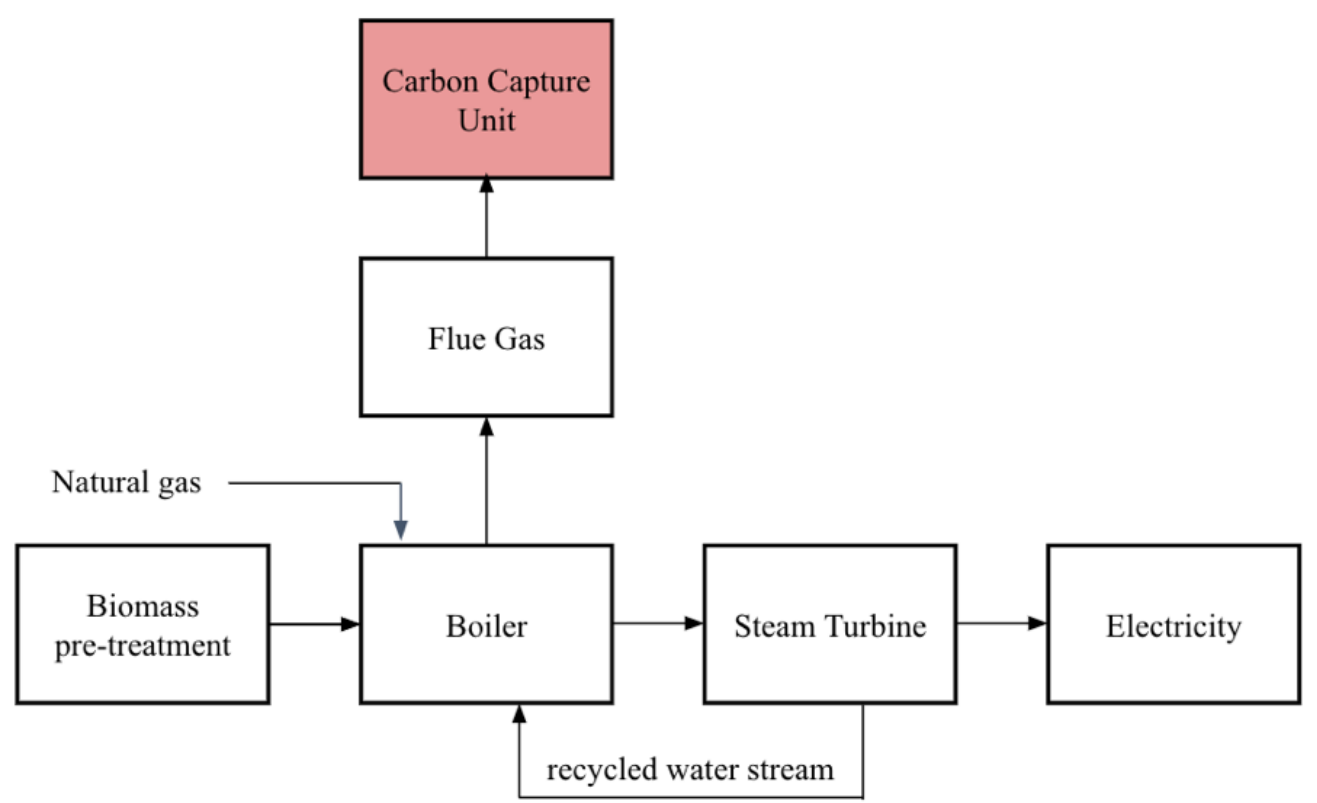

Figure 5. Block flow diagram of the process in PLTBm with firing technology. Red box represents the carbon capture unit to be installed if Bio-CCS is implemented in PLTBm with firing technology.

As studied by Burton (2009), the following reactions involved in biomass combustion are shown in Equation (4) until (7).

$$
\begin{gathered}
\mathrm{C}_{(\mathrm{s})}+\mathrm{O}_{2(\mathrm{~g})} \rightarrow \mathrm{CO}_{2(\mathrm{~g})} \\
2 \mathrm{C}_{(\mathrm{s})}+\mathrm{O}_{2(\mathrm{~g})} \rightarrow 2 \mathrm{CO}_{(\mathrm{g})} \\
2 \mathrm{H}_{2(\mathrm{~g})}+\mathrm{O}_{2(\mathrm{~g})} \rightarrow 2 \mathrm{H}_{2} \mathrm{O}_{(\mathrm{g})} \\
\mathrm{CH}_{4(\mathrm{~g})}+2 \mathrm{O}_{2(\mathrm{~g})} \rightarrow \mathrm{CO}_{2(\mathrm{~g})}+2 \mathrm{H}_{2} \mathrm{O}_{(\mathrm{g})}
\end{gathered}
$$

The first part of the combustion process focused on dewatering and thermal decomposition with release of volatiles, resulting in a gaseous stream containing 2-5\% $\mathrm{H}_{2}, 7-24 \% \mathrm{CO}_{2}, 28-66 \% \mathrm{CO}$ and $16-33 \%$ hydrocarbons (Werther, 1996). Depending on the heating rate and the supply of oxygen, the carbon consumed via combustion and gasification will leave residual ash and tar.

Similar with the gasification technology, the steam produced from the boilers then expanded through a steam turbine or steam engine to produce mechanical or electrical energy. The thermal efficiency of the biomass co-firing with pulverized coal boiler technology reaches to $92 \%$ and the power generation efficiency reaches to $45 \%$ (Xu et al., 2018).

\section{Results and Discussions}

\subsection{Emission Comparison of PLTBm Technologies}

All biomass power generation technologies emit GHG in their processes as depicted in the block flow diagrams constructed. PLTBm is considered net carbon negative since the carbon released as $\mathrm{CO}_{2}$ in the power generation processes can be bound by the biomass as it grows. Yet it is important to understand the emissions of each technology in order to select which biomass to energy conversion is better to be developed further. 
Comparison of existing LCA studies to map $\mathrm{CO}_{2}$ emission by the technologies can be seen in Table 3 . $\mathrm{CO}_{2}$ is primarily the focus of the comparison. Other GHG emissions are not converted into equivalent $\mathrm{CO}_{2}$ values. The numbers cited from these studies use the same scope and boundary, which is the power plant sub-system. The emission numbers are not net emission from a cradle-to-grave life cycle, rather focusing on the emission produced in the power plant. Emission from the construction or modification of the plant is not calculated. The LCA is done as an input/output process system inside the power generation plant. These literatures can be compared to understand emission comparison in various PLTBm technologies. Comparison with coal power plant is not done since it might give a false impression of lower emission when the scope used is only in the power plant.

Table 3. Comparison of existing LCA conducted to map $\mathrm{CO}_{2}$ emission released in IBGCC (Spath \& Mann, 1997), biomass direct firing (EREN, 2001, as cited in Carpentieri et al., 2004), 10\% biomass co-firing (Wiley et al., 2013).

\begin{tabular}{|c|c|c|c|}
\hline & IBGCC & Firing & $10 \%$ Co-firing \\
\hline Process Description & $\begin{array}{l}\text { BCL/FERCO } \\
\text { Gasifier and gas } \\
\text { turbine are } \\
\text { integrated, low } \\
\text { pressure operation }\end{array}$ & $\begin{array}{l}\text { Direct combustion in } \\
\text { steam cycle } \\
\text { configuration }\end{array}$ & $\begin{array}{l}\text { Biomass ( } 10 \% \text { of } \\
\text { total feedstock) is } \\
\text { mixed with coal for } \\
\text { combustion }\end{array}$ \\
\hline Feedstock & $\begin{array}{l}\text { Wood Chip } \\
\text { (11\% Moisture) }\end{array}$ & $\begin{array}{c}\text { Wood } \\
\text { (not specified) }\end{array}$ & Wood Waste \\
\hline Base Country & $\begin{array}{l}\text { Simulation based } \\
\text { on United States }\end{array}$ & $\begin{array}{l}\text { Burlington plant, } \\
\text { United States }\end{array}$ & $\begin{array}{l}\text { Calculation based } \\
\text { on Australian black } \\
\text { coal power plant }\end{array}$ \\
\hline $\mathrm{CO}_{2}$ emission $\left(\mathrm{g} / \mathrm{kWh} \mathrm{el}_{\mathrm{el}}\right)$ & 916 & 1400 & 880 \\
\hline
\end{tabular}

Integrated biomass gasification combined cycle studied by Spath \& Mann (1997) follows the BCL/FERCO Gasifier. Other LCA studies on IBGCC are available, but this literature is particularly selected since later in this paper it is found that BCL/FERCO Gasifier is significant for bio-CCS design in IBGCC power plants. Another interesting find is how firing can result in higher emission compared to other technologies. Possible reason is due to high moisture content, decreasing the power generation efficiency. Similar find is concluded on a hybrid life cycle inventory analysis by Yin et al. (2014) based on power plants in China. It was found that a $25 \mathrm{MW}$ biomass firing plant has an electric efficiency of $25.6 \%$, while co-firing power plant has a higher number of $27.6 \%$. A bigger capacity of $140 \mathrm{MW}$ cofiring power plant can give a $35.4 \%$ efficiency. It is proven that the addition of coal adds a significant benefit of electric efficiency, but analyzing the cradle-to-grave LCA further is important to give a better and holistic view on biomass' carbon negative performance compared to coal.

From these data it can be concluded that equipping carbon capture unit on biomass power plants can serve as a negative carbon effort. Without a carbon capture unit, those emissions are released into the atmosphere and subsequently bound by biomass. This cycle is commonly recognized as carbon closure and used when the biomass feedstock is dedicated feedstock (Mann \& Spath, 2009). LCA literatures such as Yin et al. (2014) directly acknowledge the carbon closure as $100 \%$ by assuming that all $\mathrm{CO}_{2}$ emissions released in the power plant sub-system is equal to the amount of $\mathrm{CO}_{2}$ absorbed by the biomass feedstock. When the feedstock is sourced from industrial or agricultural waste a net removal can be achieved even without carbon capture unit. Following that assumption, capturing the $\mathrm{CO}_{2}$ in the power plant can further result in a bigger removal of carbon (carbon negative). 


\subsection{Emission Reduction by Retrofitting Bio-CCS in PLTBm}

Mann and Spath (2004) provided a full view on the life cycle of various power plant cases to measure the significance in respect to the net GWP (global warming potential). Various literatures also provide the flue gas composition of the cases analyzed. The flue gas composition in Table 4 is prior to any carbon capture unit and measured in the power plant. While the net GWP is obtained from a cradle-tograve LCA. The boundary system includes the biomass sourcing/ plantation, transportation, construction and power generation. It also includes the power needed for additional carbon capture technologies in the cases where CCS is applied. The firing scenario uses waste feedstock, resulting in an obvious negative net GWP due to avoided emission. Avoided methane and $\mathrm{CO}_{2}$ emission is consequently credited to the system.

Table 4. Comparison of flue gas prior to carbon capture unit and Net GWP in various cases of power plant. (Berstad et al., 2010; Carpentieri, 2005; Mann \& Spath, 2004).

\begin{tabular}{|c|c|c|c|c|c|}
\hline & $\begin{array}{l}\text { Coal Power } \\
\text { Plant }\end{array}$ & $\begin{array}{c}\text { PLTBm } \\
\text { (firing) } \\
\text { without CCS }\end{array}$ & $\begin{array}{l}\text { PLTBm } \\
\text { (firing) } \\
\text { with CCS }\end{array}$ & $\begin{array}{c}\text { PLTBm } \\
\text { (IBGCC) } \\
\text { without CCS }\end{array}$ & $\begin{array}{c}\text { PLTBm } \\
\text { (IBGCC) } \\
\text { with CCS }\end{array}$ \\
\hline Pressure (bar) & 1 & 1 & 1 & 1 & 1 \\
\hline \multicolumn{6}{|c|}{$\begin{array}{l}\text { Flue Gas Composition } \\
(\mathrm{mol}-\%)\end{array}$} \\
\hline $\mathrm{H}_{2} \mathrm{O}$ & 6.1 & 12.8 & 12.8 & 3.8 & 3.8 \\
\hline $\mathrm{CO}_{2}$ & 14.6 & 15 & 15 & 25.96 & 25.96 \\
\hline $\mathrm{N}_{2}$ & 75.8 & 69.8 & 69.8 & 15.7 & 15.7 \\
\hline $\mathrm{O}_{2}$ & 3.4 & 2.6 & 2.6 & - & - \\
\hline $\begin{array}{l}\text { Net GWP } \\
\left(\mathrm{g} \mathrm{CO}_{2} / \mathrm{kWh}_{\mathrm{el}}\right)\end{array}$ & 847 & -410 & $-1,368$ & 49 & -667 \\
\hline
\end{tabular}

Based on the data from Table 4 it can be seen that PLTBm that uses firing technology with biomass waste can reduce $\mathrm{CO}_{2}$ emission by $148 \%$ compared to typical coal power plant. Moreover, installing carbon capture unit in said PLTBm can further reduce the specific $\mathrm{CO}_{2}$ emission by $262 \%$. A simple calculation was done to map the potential $\mathrm{CO}_{2}$ emission and its possibility for reduction by implementing CCS in the PLTBm of Indonesia. The calculation was based on existing PLTBm listed on Table 1. By assuming the power plants to operate 24 hours a day, 365 days a year and multiply it by a 0.9 availability factor, it was obtained that the total PLTBm capacities are $1119.52 \mathrm{GJ} /$ year, 1354.47 GJ/year and 260.9 GJ/year for each co-firing, firing and gasification technology, respectively.

Using the LCA data from Mann and Spath (2004), the net GWP for the listed PLTBm can be calculated. Without CCS, the net GWPs for co-firing, firing and gasification technology are 762 kilotonnes $\mathrm{CO}_{2} /$ year, -555 kilotonnes $\mathrm{CO}_{2} /$ year and 12.78 kilotonnes $\mathrm{CO}_{2} /$ year. Whereas if the carbon capture and storage technology is implemented for every PLTBm, the GWP would be 48.14 kilotonnes $\mathrm{CO}_{2} /$ year, 1,852.9 kilotonnes $\mathrm{CO}_{2} /$ year and -174.06 kilotonnes $\mathrm{CO}_{2} /$ year. It can be concluded that implementing carbon capture technology to the listed PLTBm, Indonesia can reduce its greenhouse gas emission to around 2.2 million tonnes $\mathrm{CO}_{2}$ equivalent annually. This simple calculation is a rough prediction with assumptions following Mann and Spath's. 


\subsection{Suitable Bio-CCS Unit for PLTBm in Indonesia}

From Table 1 before it can be identified that PLTBm in Indonesia utilize 2 types of technology: gasification and co-firing or firing. Depending on the capture process, different $\mathrm{CO}_{2}$ separation techniques may be used. There are four main separation technologies; solvent absorption, membranes, adsorption and cryogenics/hydrates. All four methods are suitable for gasification, while co-firing or firing is suitable for three methods, with the exception of separation using hydrates (Edström, 2013).

While active research is ongoing in both implementing CCS for gasification and co-firing, different approaches vary significantly in technologic maturity. According to Rubin et al. (2015), carbon capture systems that are integrated in PLTBm that utilizes co-firing generally have a higher technology readiness level (TRL) compared to PLTBm that utilizes gasification as seen as the table below. There are each 2 designs reviewed for each PLTBm technology in this paper, as listed in Table 5.

Table 5. Summary of technology reviewed.

\begin{tabular}{lll}
\hline PLTBm Technology & Bio-CCS Technology Design & \multicolumn{1}{c}{ Development Status } \\
\hline Gasification & NREL Design & R\&D \\
& Rhodes \& Keith Design & R\&D \\
& IBGCC+DeCO 2 & R\&D \\
Co-firing & Solvent-based & $\begin{array}{l}\text { Pilot scale by Drax Power } \\
\text { House, but could adopt the } \\
\text { commercial technology from } \\
\text { coal power plant CCS } \\
\end{array}$ \\
& & R\&D \\
\hline
\end{tabular}

PLTBm with gasification technology can gain environmental benefit by harnessing pre-combustion CCS. This applies for gasification processes that use indirectly heated systems, steam-blown systems or oxygen blown systems (Rhodes \& Keith, 2005). There has not been any existing project integrating biomass gasification and carbon capture or any retrofit systems for a direct producer gas use, but there are 3 significant designs, namely NREL design, Rhodes \& Keith design and IBGCC+DeCO 2 . Both NREL and Rhodes \& Keith designs are modeled after the BCL/FERCO gasifier system with indirectly heated systems that produce syngas through purification systems. While IBGCC+DeCO ${ }_{2}$ design was simulated using Aspen Plus. The design consists of an equilibrium reactor, Brayton/Hirn combined cycle and DEA (diethanolamine), MDEA (methyldiethanolamine) chemical absorption (Carpentieri et al., 2005). The IBGCC+DeCO 2 simulation claimed to decrease the specific $\mathrm{CO}_{2}$ emission up to $80.6 \%$ when compared to conventional IBGCC using a BCL/FERCO Gasifier (Carpentieri et al., 2005; Mann $\&$ Spath, 2004). More studies on the IBGCC $+\mathrm{DeCO}_{2}$ design needs to be done to confirm this claim since it is still in early research.

BCL/FERCO system is suitable for PLTBm rather than downstream syngas production. While the Fischer-Tropsch system is widely used, it does not provide the benefit of a higher carbon capture BCL/FERCO has. Fischer-Tropsch process includes the dilution of syngas using nitrogen, eliminating the aforementioned benefit. The BCL/FERCO system provides heat from the char combustion chamber to the gasifier using circulating sand-avoiding dilution using nitrogen. It also uses a steam reformer to shift methane. Due to that reason, this design might be applicable for PLTBm with various mixed feedstock, which is a common practice in Indonesia.

NREL design uses pressure swing adsorption (PSA) for producing $\mathrm{H}_{2}$ fuel, while Rhodes and Keith design uses glycol scrubber. By performing a simulation based on those designs, Rhodes and Keith 
concluded that the $\mathrm{CO}_{2}$ capture rate and efficiency are similar, but NREL design produces steam as a by-product with economical value, although the capital cost of such a system is more expensive (Rhodes \& Keith, 2005).

Both designs incorporate carbon capture sub-system as described by Doctor et al. (1997), illustated in Figure 6. The sub-system uses membrane processes for recovery. The membrane used is transport membrane with an absorbent fluid layered between two films. The membrane processes are carried in two phases. First phase is when the syngas is first produced. $\mathrm{CO}_{2}$ is separated from the syngas by the membrane. Second phase is after the syngas is combusted through a turbine: the membrane captures the $\mathrm{CO}_{2}$ flue gas. Flue gas of the combustion is usually a pure stream of $\mathrm{CO}_{2}$ if the oxidant used is pure $\mathrm{O}_{2}$ instead of air, which usually is the case for BCL/FERCO gasifiers.

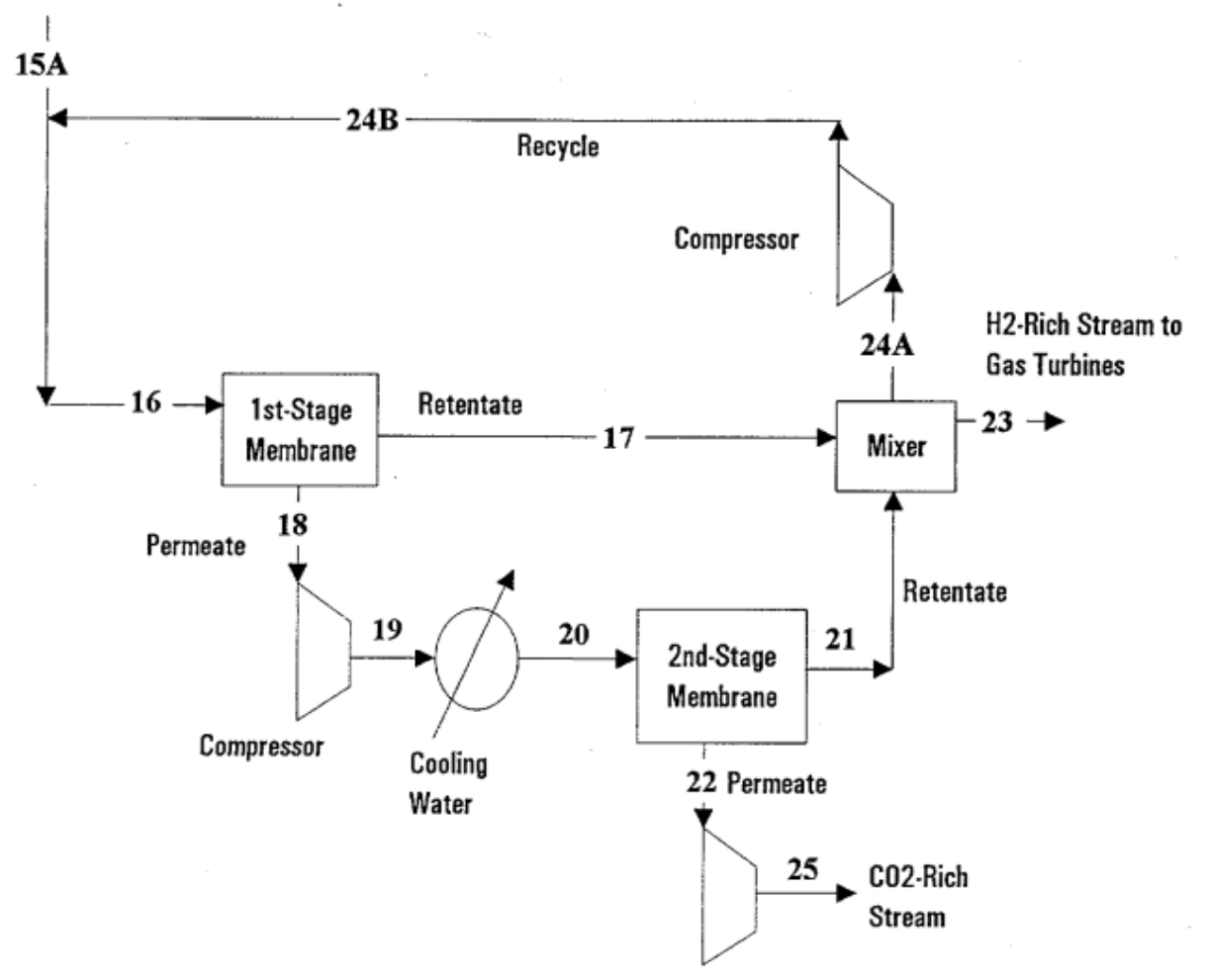

Figure 6. Carbon capture sub system (Doctor et al., 1997).

As for co-firing PLTBm, $\mathrm{CO}_{2}$ will be captured from the flue gas after the fuel has been combusted in the boiler, the process is known as post combustion carbon capture. Among other technologies, post combustion capture as an "end-of-pipe" technology is generally seen as a more viable option to be retrofitted to existing power plants, resulting in potentially less expensive transition. As mentioned before, there are several separation techniques that can be implemented in PLTBm that utilizes cofiring, among the most promising technologies are solvent-based and membrane-based separation. The summary for both separation techniques is presented in the Table 6 . 
Table 6. Comparison between solvent-based and membrane-based post combustion carbon capture technology (Adams II et al., 2017; Global CCS Institute, 2012; Songolzadeh et al., 2014).

\begin{tabular}{|c|c|c|}
\hline Parameters & Solvent-Based & Membrane-Based \\
\hline $\begin{array}{l}\text { Development for } \\
\text { commercial usage in CPI }\end{array}$ & High & Low/Niche \\
\hline $\mathrm{CO}_{2}$ Captured & $\sim 90 \%$ & $\sim 90 \%$ \\
\hline Efficiency & 46.1\% (MEA Solvent) & $25.7 \%$ (2 stages membrane) \\
\hline Cost & USD 54.8/MWh & USD 113.7/MWh \\
\hline Advantages & $\begin{array}{l}\text { 1. React rapidly } \\
\text { 2. Easy to be retrofitted to } \\
\text { existing technology } \\
\text { 3. High absorption capacities }\end{array}$ & $\begin{array}{l}\text { 1. Clean and simple process } \\
\text { 2. Continuous, steady-state } \\
\text { technology } \\
\text { 3. May not require acid gas } \\
\text { control }\end{array}$ \\
\hline Disadvantages & $\begin{array}{l}\text { 1. Equipment corrosion (require } \\
\text { acid gas control) } \\
\text { 2. Require high energy for } \\
\text { regenerating solvent }\end{array}$ & $\begin{array}{l}\text { 1. Require high energy for } \\
\text { compression }\end{array}$ \\
\hline
\end{tabular}

Solvent-based chemical absorptions technologies are already integrated in commercial cases for fossil fuel power plants (coal-CCS) such as the one that has been implemented in Boundary Dam in Estevan, Canada and Petra Nova in Texas, United States. Moreover, these methodologies can be further modified to accommodate biomass-based fuel. The project for co-firing PLTBm had also started being developed at Drax Power Station in North Yorkshire, United Kingdom in pilot scale. The CCS unit in drax is able to accommodate $90-95 \% \mathrm{CO}_{2}$ removal from the flue gas (Drax, 2020).

The process works on temperature swing principle, where $\mathrm{CO}_{2}$ is absorbed by the solvent at low temperatures and desorbed at higher temperature, as the process depicted in Figure 7. The absorber and desorber are supported by reboiler, condenser, coolers, pumps and other ancillary equipment. As we can see, the cyclic absorption and stripping process means the solvent goes through periodic heating and cooling; as the process continues, the solvent starts to degrade. To maintain capture performance, degraded solvent must be periodically replaced. Moreover, biomass based flue gases likely need advanced $\mathrm{NO}_{\mathrm{x}}$ and particle removal. To reduce the impact, washing the flue gas may be required before feeding it into the absorber (Finney, 2019). By far, amine-based solvent, such as monoethanolamine (MEA) and activated methyl diethanolamine (MDEA) and hindered amine is the most widely used solvent for this CCS system (Raksajati et al., 2018).

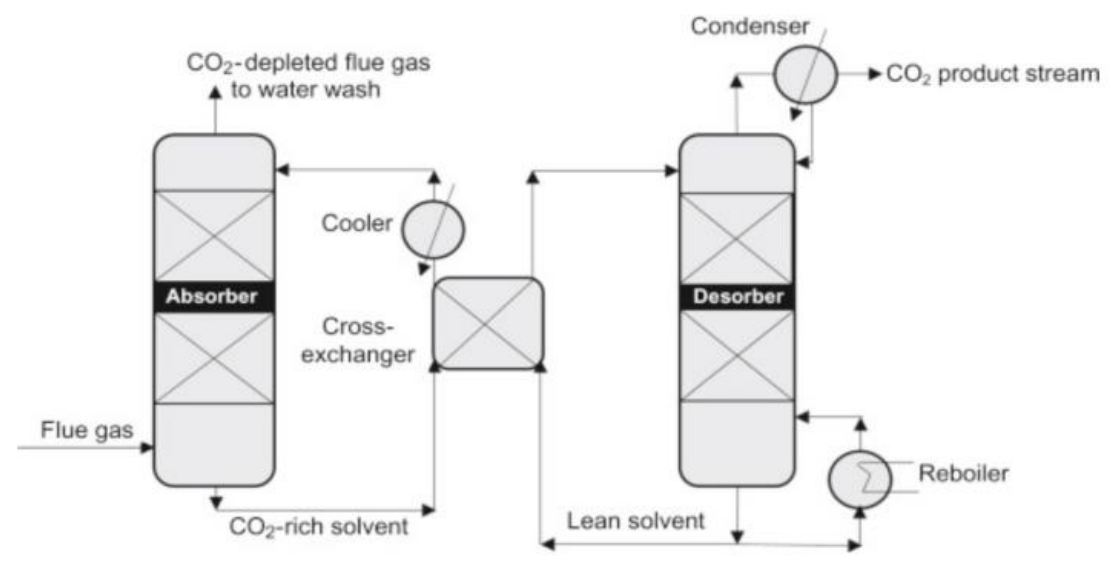

Figure 7. Schematic of solvent-based, post combustion CCS (Finney et al., 2019).

Another alternative for post-combustion CCS to be implemented in co-firing PLTBm is membranebased separation as illustrated in Figure 8. Before entering the membrane module, a wet scrubber is 
often used to cool down the flue gas. Inside the membrane module, a portion of $\mathrm{CO}_{2}$ permeates through the membrane and a stream with higher $\mathrm{CO}_{2}$ is gained on the permeate side. Compared to chemical absorption, the membrane separation is actually simpler and contains less component (Wang et al., 2017). However, to implement this, a high pressure gradient is required, while flue gas from power plants is usually close to atmospheric pressure. Adding a compressor to the system is not a viable option since it will increase capital cost along with a large energy penalty (Letcher, 2020).

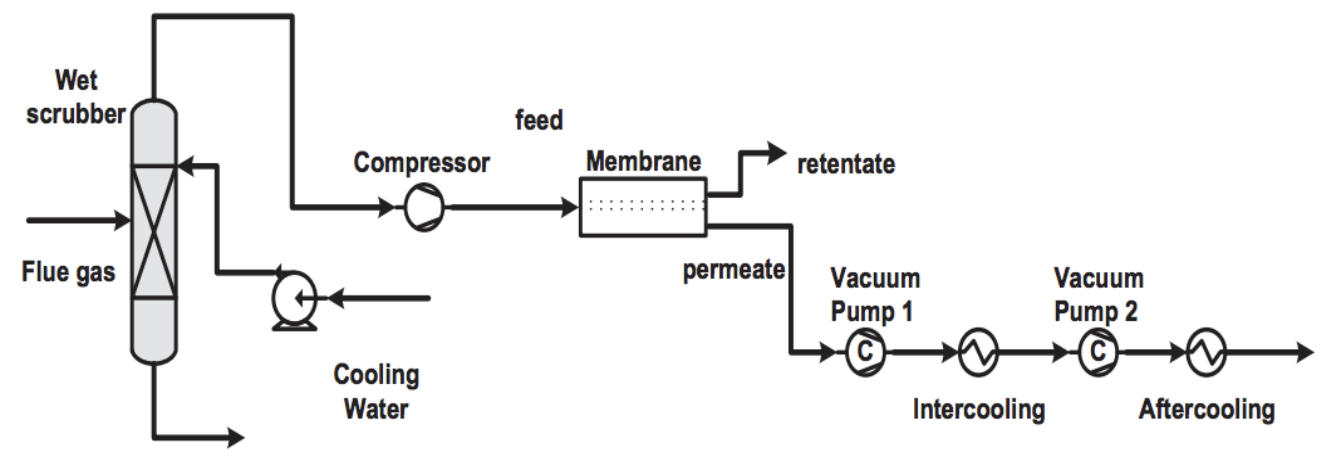

Fig. 3. Schematic of a membrane separation process

Figure 8. Schematic of membrane-based, post combustion CCS (Wang et al., 2017).

\subsection{Future Potential and Challenges of Bio-CCS Implementation in Indonesia}

Despite the known benefits of CCS and Bio-CCS, the deployment of such technology has many barriers in Indonesia, especially in the legal and financial sector. The government has realized that CCS can help the energy sector achieve the 40\% carbon reduction target through Presidential Decree No. 61 of 2011. Still, the country's main priority focuses on providing accessible energy throughout the nation.

In developing countries, CCS is seen as not economically feasible and unaffordable. International or private sector climate funds might be needed for the deployment of CCS and further bio-CCS. Specifically for bio-CCS, it is possible that the palm oil industry can contribute to research towards bioCCS in PLTBm projects. As mentioned before, there are plenty of palm oil companies in Indonesia seeking ways to leverage the sustainability of their business and manage their waste. Bio-CCS in PLTBm can be an answer to that, hence a green fund between these companies can be an opportunity.

In addition, the carbon captured from the Bio-CCS is not necessarily has to be kept in storage unit underground, some part of it can also be further processed into value-added products. Recycled carbon can be utilized as many products throughout many industries. Such utilization can help the economic feasibility of bio-CCS in PLTBm. However, it is worth noting that most of this study are still in experimental or laboratory stage and it requires plenty of considerations and further analysis to be implemented in PLTBm in Indonesia. Among all the options for $\mathrm{CO}_{2}$ utilization, feasible option to be implemented for PLTBm near future based on economic consideration is to be sold in the food and beverages industry, such as the one that has been done by Pertamina EP 3 Asset Subang Field (Candra, 2016). Other option of utilization is for optimizing oil production using enhanced oil recovery/ enhanced gas recovery (EOR/EGR) mechanism. The $\mathrm{CO}_{2}$ obtained is injected into the reservoirs will act as a substitute support for pressure maintenance. To be used for EOR/EGR mechanism, the PLTBm has to be within close proximity to the injection well. This method can be implemented in several area, such as Pertamina Block Gundih, EP Sukowati Field and BP block Tangguh (Indrawan, 2020).

Another pathway to enable bio-CCS in PLTBm is through establishing a carbon pricing policy. The government has started to highlight the possibility of carbon taxing. By having a carbon pricing policy, the energy sector will supposedly try to invest in low or negative carbon power generation. PLTBm with bio-CCS is considered as negative carbon. If a carbon market is established, it will further increase 
the potential and economical value of PLTBm with bio-CCS. By being carbon negative, companies can gain financial benefit from carbon trading.

\section{Conclusion}

The $\mathrm{CO}_{2}$ emission to be captured in the gasification process is $11-15 \%$ of the producer gas, while in cofiring it is $7-24 \%$ of the flue gas stream. There are other GHG emissions from both processes that have to be taken into account due to their damaging nature. Using biomass instead of coal in power plant reduces the electric efficiency and increases the plant's in-house emission. However, when analyzed in a wider boundary system, it is apparent that the net GWP and $\mathrm{CO}_{2}$ emission of biomass power plants are way smaller than coal power plant, even more smaller when equipped with carbon capture unit. PLTBm also brings the benefit of avoiding emissions release due to organic waste decomposition in landfill. PLTBm that uses firing technology with biomass waste can reduce $\mathrm{CO}_{2}$ emission by $148 \%$ compared to typical coal power plant while installing carbon capture unit in said PLTBm can further reduce the specific $\mathrm{CO}_{2}$ emission by $262 \%$. If carbon capture technology is implemented in all existing biomass power plants in Indonesia, it could reduce the greenhouse gas emission up to 2.2 million tonnes $\mathrm{CO}_{2}$ equivalent annually. It is found that there are 3 significant designs for gasification technology: NREL design, Rhodes \& Keith design and IGBCC+DeCO 2 design. The first two designs are not suitable to be retrofitted into existing PLTBm in Indonesia since they are based on a specific BCL/FERCO gasifier. While IGBCC+DeCO 2 design still needs further study regarding its feasibility. For firing technology, the most promising technology to be applied in the near future is solvent-based absorption because it is already on commercial scale for coal-based power plants and can be implemented for other source, e.g. biomass power plant. Bio-CCS in existing biomass power plant with firing technology is likely to be implemented in the near future compared to the gasification, because it applies the post combustion capture as an "end-of-pipe" technology which is generally seen as a more viable option to be retrofitted to existing power plants, resulting in potentially less expensive transition.

\section{References}

Adams II, T. A., Hoseinzade, L., Madabhushi, P. B., \& Okeke, I. (2017). Comparison of $\mathrm{CO}_{2}$ capture approaches for fossil-based power generation: Review and meta-study. Processes, 5. https://doi.org/10.3390/pr5030044

Anonymous. (2017). PLN perkuat kelistrikan berbasis energi terbarukan di Kalimantan. https://www.dunia-energi.com/pln-perkuat-kelistrikan-berbasis-energi-terbarukan-di-kalimantan/

Arachchige, U., Mohsin, M., \& Melaaen, M. C. (2012). Optimization of post combustion carbon capture process-solvent selection. Energy and Environment, 3(6), 861-870.

Arasto, A. (2014). Bio-CCS : feasibility comparison of large scale carbon-negative solutions. Energy Procedia, 63, 6756-6769.

Arieza, U. (2017). Nih daftar lengkap $37 \mathrm{MoU}$ dan 2 PPA milik PLN. https://economy.okezone.com/read/2017/05/19/320/1694955/nih-daftar-lengkap-37-mou-dan-2ppa-milik-pln

Asadullah, M. (2014). Barriers of commercial power generation using biomass gasification gas : A review. Renewable and Sustainable Energy Reviews, 29, 201-205.

Asian Development Bank. (2019). Carbon dioxide-enhanced oil recovery in Indonesia. https://www.adb.org/sites/default/files/publication/557161/co2-enhanced-oil-recoveryindonesia.pdf

Bates, J., Edberg, O., \& Nuttall, C. (2009). Minimising greenhouse gas emissions from biomass energy generation. Environment Agency.

Best, D., Mulyana, R., Jacobs, B., Iskandar, U. \& Beck, B. (2011). Status of CCS development in Indonesia. Energy Procedia, 4, 6152-6156. https://doi.org/10.1016/j.egypro.2011.02.624

Berstad, D., Arasto, A., Jordal, K., \& Haugen, G. (2011). Parametric study and benchmarking of NGCC, coal and biomass power cycles integrated with MEA-based post-combustion $\mathrm{CO} 2$ capture. Energy Procedia, 4, 1737-1744. https://doi.org/10.1016/j.egypro.2011.02.048

Boothman, T. (2017). Power sector : Commercial/regulatory update. [Powerpoint Slides]. https://www.pwc.com/id/en/energy-utilities- 
mining/assets/power/powerbreakfast/Commercial\%20and\%20Regulatory $\% 20$ Update $\% 20$ for $\% 20 \mathrm{t}$ he\%20Power\%20Industry\%20in\%20Indonesia\%20FINAL\%20-\%20Tim\%20Boothman.pdf

Brinkmann Consultancy. (2009). Greenhouse gas emissions from palm oil production : Literature review and proposals from the RSPO Working Group on Greenhouse Gases. http://www.rspo.org/sites/default/files/Report-GHG-October2009.pdf

Burton, S. (2009). Energy from wastewater - A feasibility study technical report. https://www.researchgate.net/publication/283908554_Energy_from_wastewater__A_feasibility_study_technical_report

Candra, S. A. (2016). Pertamina EP Subang jual CO2 untuk pengolahan makanan. https://republika.co.id/berita/ekonomi/korporasi/16/07/18/oaiavs368-pertamina-ep-subang-jualco2-untuk-pengolahan-makanan

Carpentieri, M., Corti, A., \& Lombardi, L. (2005). Life cycle assessment (LCA) of an integrated biomass gasification combined cycle (IBGCC) with $\mathrm{CO} 2$ removal. Energy Conversion and Management, 46(11-12), 1790-1808. https://doi.org/10.1016/j.enconman.2004.08.010

Ciferno, J., Klara, J., \& Wimer, J. (2007). Outlook for carbon capture from pulverized coal and integrated gasification combined cycle power plant. CCS Economic Analyses.

Consoli, C. (2019). Bioenergy and carbon capture and storage. Global CCS Institute.

CTCN. (2014). Biomass combustion and co-firing for electricity and heat. https://www.ctcn.org/technologies/biomass-combustion-and-co-firing-electricty-and-heat.

Dani, S. \& Wibawa, A. (2018). Challenges and policy for biomass energy in Indonesia. International Journal of Business, Economics and Law, 15(5), 41-44.

Dennis, B., Mulyana, R. Jacobs, B., Iskandar, U. P., \& Beck, B. (2011). Status of CCS development in Indonesia. Energy Procedia, 4, $6152-6156$.

Doctor, R. D., Molburg, J. C., \& Thimmapuram, P. R. (1997). Oxygen-blown gasification combined cycle : carbon dioxide recovery, transport, and disposal. Energy Conversion and Management, 38, S575-S580. https://doi.org/10.1016/S0196-8904(96)00330-5

Drax. (2020). Negative emissions pioneer Drax and leading global carbon capture company Mitsubishi Heavy Industries Group - announce new BECCS pilot. https://www.drax.com/press_release/negative-emissions-pioneer-drax-and-leading-global-carboncapture-company-mitsubishi-heavy-industries-group-announce-new-beccs-pilot/

E4tech. (2009). Review of technologies for gasification of biomass and wastes. http://wiki.gekgasifier.com/f/Review+of+Biomass+Gasification+Technologies.NNFCC.Jun09.pdf

Edström, E. \& Öberg, C. (2013). Review of bionergy with carbon capture and storage (BECCS) and possibilities of introducing a small-scale unit. [Master of science thesis, KTH School]. KTH School of Industrial Engineering and Management.

Energia News. (2020). Komitmen pertamina power Indonesia untuk terus mengembangkan energi bersih. https://pertamina.com/id/news-room/energia-news/komitmen-pertamina-power-indonesiauntuk-terus-mengembangkan-energi-bersih

Engström, F. (1999). Overview of power generation from biomass. 1999 Gasification Technology Conference; 1999 October 19 - October 20; San Francisco, California.

European Biofuel Technology Platform (EBTP) \& Zero Emission Fossil Fuel Power Plants (ZEP). (2012). Biomass with CO2 capture and storage. https://www.etipbioenergy.eu/images/EBTP-ZEPReport-Bio-CCS-The-Way-Forward.pdf

Finney, K. N., Akram, M., Diego, M. E., Yang, X., \& Pourkashanian, M. (2019). Carbon capture technologies. Bioenergy with Carbon Capture and Storage, 2, 15-45. https://doi.org/10.1016/B9780-12-816229-3.00002-8

Firsawan, A. H. (2018). Dua investor asing bangun pembangkit listrik Rp 16,4 Triliun di Aceh. https://sumatra.bisnis.com/read/20180810/534/826827/dua-investor-asing-bangun-pembangkitlistrik-rp163-triliun-di-aceh

Fitriana, I., Anindhita, F., Sugiyono, A., Abdul Wahid, L. O., \& Adiarso. (2017). Outlook energi Indonesia 2017: Inisiatif pengembangan teknologi energi bersih.

Garrido, L., Mumbunan, S., \& Erdenesanaa, D. (2019). Indonesia charts a new, low carbon development path. Will other countries follow suit?.

https://www.wri.org/blog/2019/03/indonesia-charts-new-low-carbon-development-path-willother-countries-follow-suit 
Global CCS Institute. (2012). Post Combustion Capture (PCC). $\mathrm{CO}_{2}$ Capture Technology.

Gokcol, C., Dursun, B., Alboyaci, Bora \& Sunan, E. (2009). Importance of biomass energy as alternative to other sources in Turkey. Energy Policy, 37, 424-431.

Gough, C. \& Upham, P. (2011). Biomass energy with carbon capture and storage (BECCS or BioCCS). Greenhouse Gases: Science and Technology. 1. 324 - 334. https://doi.org/10.1002/ghg.34

Growth Asia. (2012). PLTU biomassa growth steel group.

Handoyo. (2019). PTPN $V$ resmikan PLT biogas dengan kapasitas $700 \mathrm{KW}$. https://industri.kontan.co.id/news/ptpn-v-resmikan-plt-biogas-dengan-kapasitas-700kw

Himawan, A. (2017). PLN gandeng empat pengembang energi terbarukan di Kalimantan. https://www.suara.com/bisnis/2017/05/17/165711/pln-gandeng-empat-pengembang-energiterbarukan-di-kalimantan.

Hirschmann, R. (2020). Production volume of palm oil in Indonesia 2012-2019. https://www.statista.com/statistics/706786/production-of-palm-oil-in-indonesia/

Hogelund, C. (1981). Agricultural residues as fuel for producer gas generation. Report from a test series with coconut shells, coconut husks, wheat straw and sugar cane. https://www.osti.gov/etdeweb/biblio/8134444

Humas EBTKE. (2018, September 24). PLTBm Siantan, PLT biomassa swasta pertama di Kalimantan Barat.

https://ebtke.esdm.go.id/post/2018/09/24/2022/pltbm.siantan.plt.biomassa.swasta.pertama.di.kalim antan.barat

Humas EBTKE. (2019). PLTBm Bambu Siberut terangi 3 desa, hemat biaya penyediaan listrik hingga 14 miliar.

https://ebtke.esdm.go.id/post/2019/09/18/2340/pltbm.bambu.siberut.terangi.3.desa.hemat.biaya.pe nyediaan.listrik.hingga.14.miliar

Humas Prov. Kaltim. (2014). PLTU tambahan listrik dari Embalut dan Peaking. https://kaltimprov.go.id/berita/pltu-tambahan-listrik-dari-embalut-dan-peaking

Humas PTPN V. (2020). Di PTPN V, Menristek resmikan pemanfaatan listrik dari pembangkit listrik biogas.https://ptpn5.com/2020/03/di-ptpn-v-menristek-resmikan-pemanfaatan-listrik-daripembangkit-listrik-biogas/

IEA Bioenergy. (2009). Annual report 2009 IEA Bioenergy. https://www.ieabioenergy.com/wpcontent/uploads/2013/10/IEA-Bioenergy-2009-Annual-Report.pdf

IKPT. (2019). Siberut PLTBm inaugurated. http://www.ikpt.com/blog/2019/09/18/siberut-pltbminaugurated/

Irawan, R. (2020). Tiga proyek CCUS-EOR bisa tekan emisi CO2 hingga 48 Juta Ton. https://www.dunia-energi.com/tiga-proyek-ccus-eor-bisa-tekan-emisi-co2-hingga-48-juta-ton/

Jonan, I. (2018). Renewable energy for sustainable development. [Powerpoint Slides]. https://berkas.dpr.go.id/ksap/pfsd2018/page/Ignasius\%20Jonan.pdf

Kementrian Lingkungan Hidup dan Kehutanan. (2017). Portal data kementrian lingkungan hidup dan kehutanan. https://www.menlhk.go.id/site/single_post/171

Kementrian PPN. (2018). Resmikan perusahaan Independent Power Producer Biomassa Pertama di Kalimantan Barat, Mentri Bambang : PLTBm Siantan mampu produksi $15 \mathrm{MW}$. https://www.bappenas.go.id/id/berita-dan-siaran-pers/resmikan-perusahaan-independent-powerproducer-biomassa-pertama-di-kalimantan-barat-menteri-bambang-pltbm-siantan-mampuproduksi/

Khalil, E. (2008). Steam power plants. https://doi.org/10.2495/978-1-84564-062-0/04

Khorshidi, Z., Ho, M. T., \& Wiley, D. E. (2013). Techno-economic study of biomass co-firing with and without $\mathrm{CO} 2$ capture in an Australian black coal-fired power plant. Energy Procedia, 37, 60356042 .

Kusuma, H. (2019). Pembangkit berbahan kayu bikin tebal kantong warga perbatasan. https://finance.detik.com/energi/d-4785792/pembangkit-berbahan-kayu-bikin-tebal-kantongwarga-perbatasan

Kusuma, H. (2019). Perbatasan Karimun punya pembangkit listrik berbahan bakar kayu. https://finance.detik.com/energi/d-4785744/perbatasan-karimun-punya-pembangkit-listrikberbahan-bakar-kayu 
Leung, D. Y.C., Caramanna, G., \& Maroto-Valer, M. M. (2014). An overview of current status of carbon dioxide capture and storage technologies. Renewable and Sustainable Energy Reviews, 39, 426-443. https://doi.org/10.1016/j.rser.2014.07.093

Letcher, T. M. (2020). Future Energy: Improved Sustainable and Clean Options for our Planet, 3, 757 792. https://doi.org/10.1016/C2018-0-01500-5

Liu, H., Yin, X., \& Wu, C. (2014). Comparative evaluation of biomass power generation systems in China using hybrid life cycle inventory analysis. The Scientific World Journal, 2014, 1-14. https://doi.org/10.1155/2014/735431

Mahamud, R., Khan, M. M., Rasul, M., \& Leinster, M. (2011). Post combustion carbon capture and storage in existing coal power plant: importance and recent development. $8^{\text {th }}$ Internatiol Conference on Heat Transfer, Fluid Mechanics, and Thermodynamics; 2011 July 11 - July 13; Pointe Aux Piments, Mauritus.

Mann, M. K., \& Spath, P. L. (1997). Life cycle assessment of a biomass gasification combined-cycle system. National Renewable Energy Laboratory. https://www.osti.gov/servlets/purl/10106791uAMrZ0/webviewable/

Mayhead, G. J. (2010). Biomass to electricity. California Agriculture, 66(1), 6-7.

McKendry, Peter. (2002). McKendry, P.: Energy production from biomass (Part 1): Overview of biomass. Bioresource technology. 83. 37-46.

Mohammed, M. A. A., Salmaiton, A., Mohamad, A., Omar, R., Taufiq-Yap., Y. H. \& Fakhru'l-Razi, A. (2012). Catalytic gasification of empty fruit bunch for enhanced production of hydrogen rich fuel gas. Pertanika Jurnal Sci. \& Technol, 20(1), 139-149.

Novianti, S., Biddinika, M. K., Prawisudha, P., \& Yoshikawa, K. (2013). Upgrading of palm oil empty fruit bunch employing hydrothermal treatment in lab-scale and pilot scale. Procedia Environmental Science, 20, 46-54.

Ogada, T. \& Werther, J. (1996). Combustion characteristics of wet sludge in a fluidized bed: Release and combustion of the volatiles. Fuel 1996, 75, 617-626.

Padang, Y. A., Mirmanto, M. , Syahrul, S., Sinarep, S., \& Pandiatmi, P. (2020). Pemanfaatan energi alternatif dan terbarukan. Jurnal Karya Pengabdian, 2(2), 77-84.

Permatasari, R., Sugiyono, \& Wulandari, N. (2011). Kajian pengaruh suhu terhadap densitas dan sifat reologi minyak sawit kasar. [Library of IPB University]. Institut Pertanian Bogor. https://repository.ipb.ac.id/handle/123456789/53063

PLN Enjiniring. (2017). Pembangkit Listrik Tenaga Biomassa (PLTBm). https://plne.co.id/uploads/Prospektus\%20PLTBm.pdf

Primadita, D.S., Kumara, I. N. S., \& Ariastina, W. G. (2020). A review on biomass for electricity generation in Indonesia. Journal of Electrical, Electronics, and Informatics, 4(1), 4.

Rahino, R. P. (2017). PT Carpediem targetkan operasional pembangkit listrik biomassa di Sintang tahun 2019. https://pontianak.tribunnews.com/2017/04/24/pt-carpediem-targetkan-operasionalpembangkit-listrik-biomassa-di-sintang-tahun-2019?page $=2$

Raksajati, A., Ho, M. T., \& Wiley, D. (2018). Comparison of solvent development options for capture of CO2 from flue gases. Industrial \& Engineering Chemistry Research, 57(19), B-K.

Raksajati, A., Ho, M. T., \& Wiley, D. (2018b). Solvent development for post-combustion CO2 Capture: Recent development and opportunities. MATEC Web of Conferences, 156, 03015. https://doi.org/10.1051/matecconf/201815603015

REEP \& LCORE-INDO. (2017). Bioenergy investment and project development in Indonesia. [Powerpoint Slides]. Lcore_book.

http://202.67.11.4/lcore_book/office/output/document/104_publication_Bioenergy_Investment_an d_Project_Development.pdf

Reijnders, L., \& Huijbregts, M. A. J. (2008). Palm oil and the emission of carbon-based greenhouse gases. Journal of Cleaner Production, 16(4), 477-482. https://doi.org/10.1016/j.jclepro.2006.07.054

Restrepo-Valencia, S. \& Walter, A. (2019). Techno-economic assessment of bio-energy with carbon capture and storage systems in a typical sugarcane mill in Brazil. Energies, 12(6), 1129.

Rhodes, J. S. \& Keith, D. W. (2005). Engineering economic analysis of biomass IGCC with carbon capture and storage. Biomass \& Bionergy, 29, 440-450. 
Ricardo Energy \& Environment. (2018). Analysing the potential of bioenergy with carbon capture in the UK to 2050. Report for BEIS, 4, 12-30.

Rubin, E. S., J. E. Davison, \& H. J. Herzog. (2015). The cost of $\mathrm{CO}_{2}$ capture and storage. International Journal of Greenhouse Gas Control, 40, 378-400.

Rupani, P. F. R., Singh, P., Ibrahim, M. H., \& Esa, N. (2010). Review of current palm oil mill effluent (POME) treatment methods: Vermicomposting as a sustainable practice. World Applied Sciences Journal, 11(1), 70-81.

Rycoft, M. (2019). Biomass gasification for large-scale electricity generation. https://www.ee.co.za/article/biomass-gasification-for-large-scale-electricity-

generation.html\#: :text=However\%20biomass\%20gasification\%20is\%20expected,to\%2020\%20M Wth\%20or\%20more

Sansaniwal, S.Rosen, M. \& Tyagi, S. (2017). Global challenges in the sustainable development of biomass gasification: An overview. Renewable and Sustainable Energy Reviews, 80, 23-43. https://doi.org/10.1016/j.rser.2017.05.215

Senoaji, A. (2013). Upaya pengelolaan lingkungan hidup (UKL) dan upaya pemantauan lingkungan hidup (UPL). PT. Primanusa Energi Lestari.

Servert, J. \& San Miguel, Guillermo. (2011). Hybrid solar - Biomass plants for power generation; technical and economic assessment. Global Nest Journal. 13.

Songolzadeh, M., Soleimani, M., Ravanchi, M. T., \& Songolzadeh, R. (2014). Carbon dioxide separation from flue gases : A technological review emphasizing reduction in greenhouse gas emissions. The Scientific World Journal.

Spath, P. L. \& Mann, M .K. (2004). Biomass power and conventional fossil systems with and without CO2 sequestration - Comparing the energy balance, greenhouse, gas emissions, and economics. U.S. Department of Commerce.

Sudaryanti, D. A., Fauzi, A., Dharmawan, A. H., \& Putri, E. I. K. (2017). Bioenergi dan transformasi sosial ekonomi pedesaan. Sodiality : Jurnal Sosiologi Pedesaan, 5(3), 191-200.

Sugiyono, A., Adiarso, A., Dewi, R. E. P., Yudiarto, Y., Wijono, A., \& Larasati, N. (2019). Analisis keekonomian pembangunan pembangkit listrik tenaga biogas dari POME dengan Continuous Stirred Tank Reactor (CSTR). Majalah Ilmiah Pengkajian Industri, 13(1), 1-92. https://doi.org/10.29122/mipi.v13i1.3232

Suharyati, Pambudi, S. H., Wibowo, J. L., \& Pratiwi, N. I. (2019). Indonesia energy outlook 2019 (Vol. 1). https://doi.org/ISSN 2527-3000

Tobari, T. (2016). Kepala BPPT dan Bupati Pelalawan apreasiasi pembangungan PLTBg. http://infopublik.id/read/149655/kepala-bppt-dan-bupati-pelalawan-apresiasi-pembangunanpltbg.html

Visvanathan, C., Setiadi, T., Herarth, G., \& Shi, H. (2009). Eco-industrial clusters in urban-rural fringe areas. Asian Institute of Technology.

Wang, Y. \& Zhao, L. (2017). A review of post-combustion $\mathrm{CO}_{2}$ capture technologies from coal-fired power plants. Energy Procedia, 114, 650-665. https://doi.org/10.1016/j.egypro.2017.03.1209

Winarto, Y. (2015). Selasa depan, KEK Sei Mangkei siap beroperasi. https://industri.kontan.co.id/news/selasa-depan-kek-sei-mangkei-siap-beroperasi.

World Bank. (2015). The Indonesia Carbon Capture Storage (CCS) capacity building program. [World Bank Document].

https://openknowledge.worldbank.org/bitstream/handle/10986/22804/Carbon0Capture00Plants0in OIndonesia.pdf? sequence $=1 \&$ isAllowed $=\mathrm{y}$

Xu, J.P., Huang, Q., Lv, C.G., Feng, Q., \& Wang, F.J. (2018). Carbon emissions reductions oriented dynamic equilibrium strategy using biomass-coal co-firing. Energy Policy 2018, 123, 184-197. 